\title{
Application of Vacuum Frying Machines in Various IKM Banana Processes to Improve Employee Expenses PHK PT Kertas Leces Probolinggo District Provinsi Jawa Timur
}

\author{
Author \\ Trias Setyowati, Kosjok, Wiwik Suharso \\ Correspondence \\ Universitas Muhammadiyah Jember \\ trias@unmuhjember.ac.id, kosjoko@unmuhjember.ac.id,wiwiksuharso@unmuhjember.ac.id 3
}

\begin{abstract}
During the rainy season traditional production activities for sale and banana chips cannot be done because the processed raw material for bananas must be dried in the sun for three consecutive days so that the quality is good. This condition is experienced by mother's wife of former employees of layoffs PT Kertas Leces Faizzah Probolinggo in SMEs, especially at the height of the rainy season in December and January. The weather forecast for BMKG in Probolinggo Regency in January 2017 shows high rainfall of more than $400 \mathrm{~mm}$ lasted until March. Therefore, this activity aims to apply a vacuum frying frying machine so that partners can still produce with good quality when it is rainy or cloudy. Vacuum frying can fry the raw material of wet bananas into high quality products and banana chips. The advantages of the vacuum frying method are non-charred products, the nutrient content does not disappear, the taste and aroma according to the original ingredients, crisp, do not need preservatives and artificial flavor enhancers. Whereas the Surya Makmur Farmer Group faces the problem of the price of slash and the location of banana plants below the market price. So that the specific target to be achieved is the strengthening of business units providing processed sale and banana chips with sustainable production and managed by financial management and retail-based marketing by IKM Faizzat, as well as the availability of banana supply at market prices from farmers in the Farmers' Group. The solution provided by the Implementing Team is in the form of machine procurement and testing, production training and mentoring, and socialization. The procurement and testing of vacuum frying machines as frying machines, and spinner machines as oil residues are left over in sale products and banana chips. The training activity begins with the production of standard operating procedures, production training and machine maintenance documents. Socialization activities are given to partners so that they can be continued in the production of various banana processed products independent.
\end{abstract}

Keywords: vacuum frying, spinner, sale, banana chips, IKM faizzat

Received: 29 November 2018. Accepted: 28 Desember 2018

\section{Introduction}

Banana (Musa parasidiaca) is one of the national superior fruit commodities. Indonesia occupies the first position based on harvest area, banana production, and diversity of bananas. In 2013 the total national banana production reached 6.28 million tons or $50 \%$ of banana production in Asia thus providing an opportunity for the use and commercialization of bananas. Of the total production, $90 \%$ is used for domestic consumption and $10 \%$ for export. The percentage of household demand includes consumption of fresh bananas on average by $18.56 \%$. While hotels, restaurants and processed food industries made from bananas, on average, reached $76.74 \%$. Banana fruit can be a processed food raw material such as chips, sale, puree, fruit juice, jam, syrup, dodol (Ministry of Agriculture, 2014). This condition can be utilized by banana farmers and banana processed Small and Medium Industry (IKM) actors to increase added value, competitiveness and welfare through diversification of processed banana products.

IKM Faizzah Village Leces, Leces Subdistrict, Probolinggo Regency is a business group of 6 employees of the ex-employee of PT Kertas Leces. This joint venture began in March 2013 due to the family economy's economy after Termination of Employment (PHK) without severance pay. IKM Faizzat has produced sale-processed products and banana chips with traditional equipment so that product quality is low and high dependence on weather. Every rainy season production activity cannot be carried out because the raw material of processed wet bananas must be dried in the sun for three consecutive days for good quality. While the BMKG Probolinggo weather forecast data for 
January 2017 predicts high intensity rain (more than $400 \mathrm{~mm}$ ) on average each year until March (bpbd.probolinggokab.go.id). IKM Faizzah does not have a solution to this problem and hopes that there will be assistance for empowerment programs and equipment that enable production of good quality when the weather is rainy or cloudy so as not to lose income. The Surya Makmur Farmer Group is a group of farmers of rice, corn, onion, jackfruit king type and kepok banana which has 50 farmers and manages 30 hectares of land. Many banana trees are planted in homes, paddy fields, tegal and unproductive land, where the number is estimated to reach 5,000 trees with a total production of bananas 90 tons per hectare. The abundance of crop yields is not followed by high prices because generally farmers directly sell bananas to traders with a price system for land clearance, so the selling price is very low or below the price market.

The development of the banana processing industry through partnerships between farmers and small business actors has great business opportunities. The supporting factors are abundant banana raw material availability, empowerment of women workers in ex-lay off employees, support for technology-based production processes, the shelf life of old processed products up to one year and light volume will facilitate distribution, many regional product sales agents, the high selling price of processed products will increase the income of farmers and small businesses. The above business opportunities cannot be utilized by IKM Faizzat because they do not have the knowledge, capital and technological equipment that can produce banana processed products with high quality continuously without depending on the weather, limited human resources. From the analysis of the situation of the two partners, this activity aims to implement a vacuum frying and spinner machine to improve the quality of processed banana products and ensure the sustainability of production during rainy or cloudy weather so as to create added value. The advantages of vacuum frying are non-charred products, nutrients do not disappear, the taste and aroma according to the original ingredients, crisp, do not need preservatives and artificial flavor enhancers (Setyadjit et al, 2010). The specific target to be achieved is the strengthening of the banana chips sale and banana business unit with IKM Faizzat vacuum frying and spinner technology, as well as the availability of banana fruit supplies at market prices from farmers.

\section{Method}

Based on the solutions and output targets proposed in this PKM activity, the stages in implementing the solutions described in the field of production activities are shown in Table 1 . The financial management activities of accounting and retail marketing are shown in Table 2.

Table 1. Stages of Production Activities

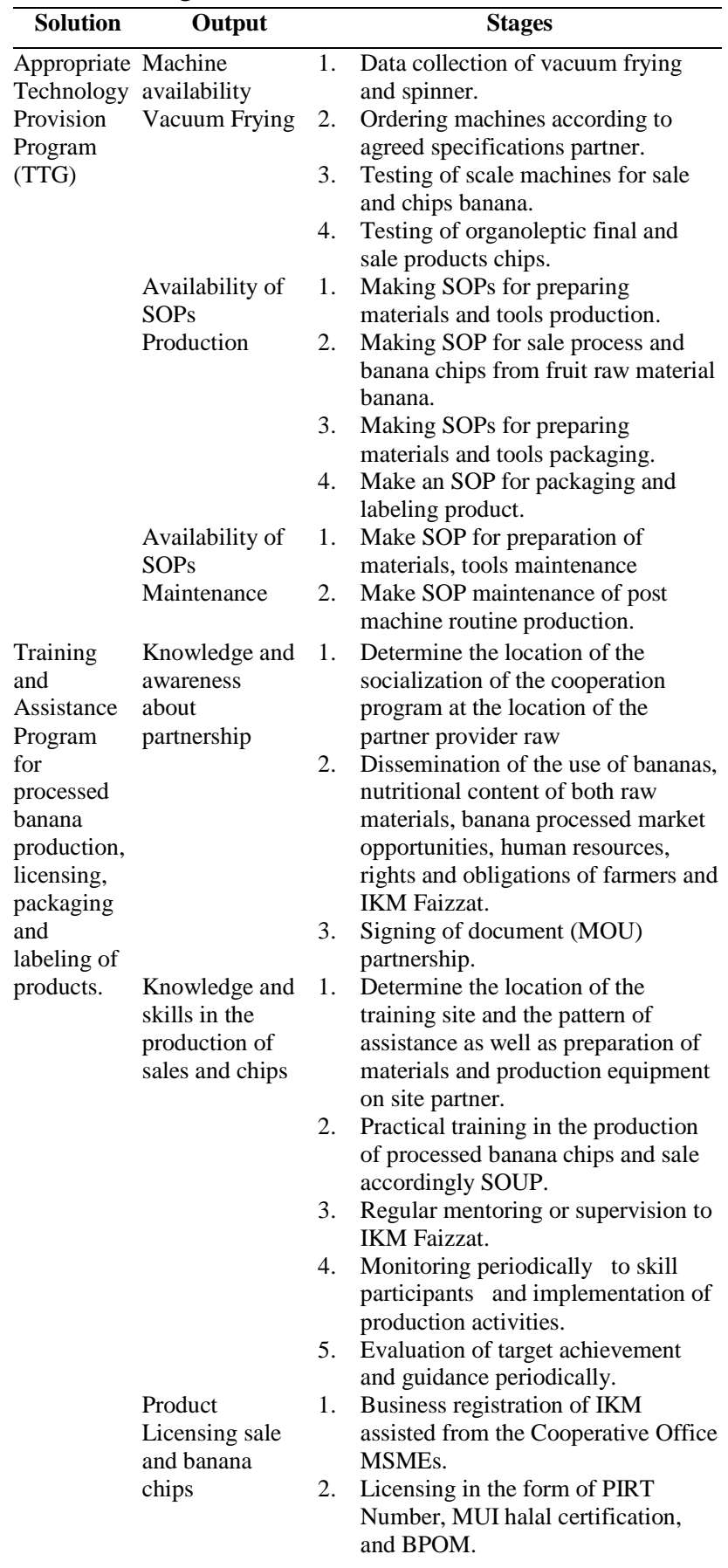




\begin{tabular}{lll}
$\begin{array}{l}\text { Packaging } \\
\text { products for sale } \\
\text { and chips }\end{array}$ & 1. & $\begin{array}{l}\text { Identify safe packaging materials } \\
\text { and tools sealer. } \\
\text { banana }\end{array}$ \\
2. & $\begin{array}{l}\text { Manufacture of packaging products } \\
\text { from processed banana products. }\end{array}$ \\
$\begin{array}{l}\text { Labeling } \\
\text { final product } \\
\text { packaging }\end{array}$ & 1. $\begin{array}{l}\text { Application of screen printing on } \\
\text { product packaging end. } \\
\text { from each product } \\
\text { Giving barcode code, price, } \\
\text { expiration date product. }\end{array}$ \\
\hline
\end{tabular}

In providing Appropriate Technology, the Proponent Team acts as: (1) Providers of vacuum frying and spinner machines according to agreed specifications of partners, (2) Vacuum frying and spinner machine testers of scale of production, (3) Production of SOP documents based on best practice results ( best practice) with an experimental approach to temperature and time settings, (4) Maker of final product packaging SOP documents. Mitra Tani Group acts as a provider of information on specifications of the king jackfruit banana, kepok banana. Faizzat SME Partners acts as an information provider and a sale of production capacity of banana chips in accordance with market demand, production scheduling processed bananas and maintenance of machinery production.

The Proposal Team as: (1) Speakers of socialization, and mediators of signing the MOU, (2) Companion of production activities, monitoring and evaluation (monev) after production activities, product licensing, product packaging and labeling. Submission of material in the form of discussion and question and answer, practice, supervision, continuous monitoring and evaluation to achieve independence in production with good product quality. Farmer Group partners act as socialization participants and signed partners in the MOU. Faizzat SME partners as participants in the socialization and partners who signed the MoU, mentoring trainees and production processes, licensing, packaging and labeling of products end.

Table 2. Stages of Activities in Financial Management and Marketing

\begin{tabular}{|c|c|c|}
\hline Solution & Output & Stages \\
\hline $\begin{array}{l}\text { Model } \\
\text { Provision }\end{array}$ & $\begin{array}{l}\text { Availability of } \\
\text { models }\end{array}$ & $\begin{array}{l}\text { 1. Create a financial-based } \\
\text { administration model UKM. }\end{array}$ \\
\hline Program & Accounting & 2. Make a SOP for the \\
\hline $\begin{array}{l}\text { Finance and } \\
\text { Marketing, } \\
\text { and }\end{array}$ & Finance & $\begin{array}{l}\text { transaction of purchase, } \\
\text { production, sales, payroll and } \\
\text { reporting. }\end{array}$ \\
\hline Mentoring & & $\begin{array}{l}\text { 3. Assistance in implementing } \\
\text { SOP models finance. }\end{array}$ \\
\hline
\end{tabular}

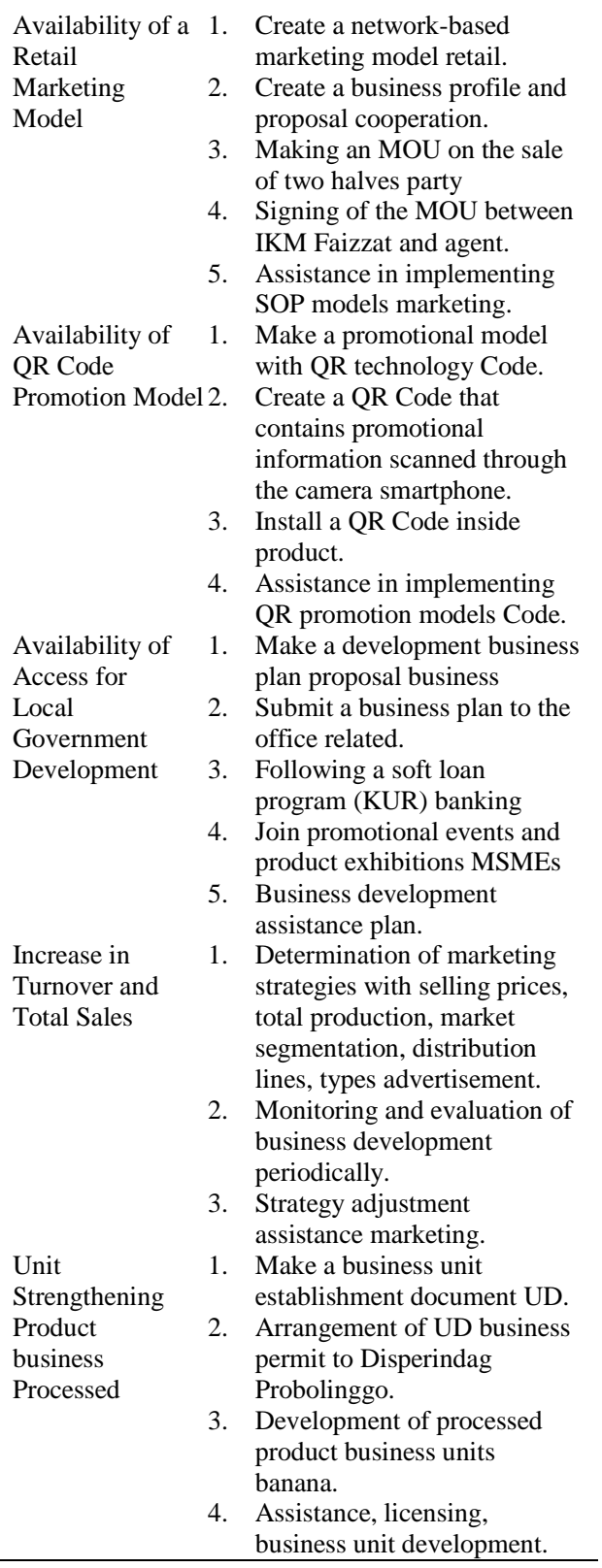

The Proposal Team acts as (1) Designer of accounting financial models, retail network-based marketing models, and QR Code promotion models, (2) Designers of business plan proposals, UD business establishment documents, and help access financing to banks and access to guidance to Regional Governments, (3) Trainers and facilitators of training activities and practices in applying both models in business activities, (4) Monitoring and evaluation of the application of models, business development and strengthening of business units in partner business activities. IKM Faizzat partners as training and mentoring participants as well as implementers who implement financial and marketing models in the activities carried out. This is because production and business management activities will be 
handled by IKM Faizzat members, and the farmers act as suppliers of fruit raw materials banana.

\section{Results and Outputs}

In this Community Partnership Program, the Implementation Team has conducted a series of activities consisting of coordination of the implementation team and partners, procurement of vacuum frying and spinner machines, testing of production machines based on standard operating procedures, training and production assistance, socialization to partners and the community.

\section{Coordination Activities}

The PKM Implementation Team consists of the chairman, members, and is assisted by two students. The Implementation Team conducts coordination activities in four stages. The first stage is the initial coordination to plan the activity schedule and division of tasks in Table 3. The second stage is continued coordination with the two partners to build commitment and cooperation related to the availability of banana supply and the sustainability of production activities. The third stage is coordination with the LPPM Muhammadiyah Jember University to report on the achievements of the activities, get direction and input. The fourth stage is coordination before socialization activities to partners.

Table 3. Schedule of 2018 PKM Implementation

\begin{tabular}{|c|c|c|}
\hline No. & Date & Description of PKM Activities \\
\hline 1. & $\begin{array}{l}\text { March - } \\
\text { September } \\
2018\end{array}$ & $\begin{array}{l}\text { Coordination between Implementing } \\
\text { Team, Students, IKM Partners and } \\
\text { Farmers Group, LPPM Muhammadiyah } \\
\text { Jember University, and relevant } \\
\text { government stakeholders. }\end{array}$ \\
\hline 2. & $\begin{array}{l}\text { April - May } \\
2018\end{array}$ & $\begin{array}{l}\text { Determination of engine specifications } \\
\text { according to the needs of partners, } \\
\text { ordering vacuum frying and spinner } \\
\text { production machines. }\end{array}$ \\
\hline 3. & June 2018 & $\begin{array}{l}\text { Preparation of standard operating } \\
\text { procedures for using vacuum frying and } \\
\text { spinner machines, as well as production } \\
\text { testing to produce a variety of } \\
\text { processed banana products, especially } \\
\text { sale and chips. banana. }\end{array}$ \\
\hline 4. & July 2018 & $\begin{array}{l}\text { Training and mentoring of various } \\
\text { banana-processed production, } \\
\text { socialization to the benefit partners for } \\
\text { the application of machinery in } \\
\text { production activities, quality } \\
\text { product and product packaging design. }\end{array}$ \\
\hline 5. & August 2018 & $\begin{array}{l}\text { Preparation and application of IKM } \\
\text { financial models. Faizzat, management of } \\
\text { the types of business licenses and } \\
\text { products needed, and models }\end{array}$ \\
\hline
\end{tabular}

retail marketing of various banana processed products.

\author{
Improved quality control of various \\ banana processed products, labeling the \\ final product. Expansion of the SME \\ product marketing network, monitoring \\ and \\ evaluation (monev) of the development \\ of IKM business units. Faizzat and its \\ derivative impacts for increasing \\ community income.
}

The activity of providing vacuum frying and spinner machines

The Implementing Team and partners determine the specifications of vacuum frying and spinner machines. The main specifications desired by partners are related to the capacity of a vacuum frying machine with a minimum of $10 \mathrm{~kg}$, a maximum electric power requirement of 1000 watts, and stainless plate material. The main specifications spinner engine capacity of at least 5 $\mathrm{kg}$, needs a maximum of 700 watts of electrical power. Based on the needs of partners, the Team conducts searches and surveys of workshop providers of processed food production equipment, and ordering machinery. The vacuum frying and spinner machines that have been submitted to partners are shown in Figure 1. The vacuum frying machine consists of a water jet vacuum pump component, frying tube, condenser, heating unit, operation control unit, stirrer section. While the spinner engine consists of basket or basketball, electric dynamo, spinner body, rotary shaft, vbelt. The Implementation Team is directly involved in delivering machine vacuum frying and spinner to location partner in Perum Leces Permai C. 14 A Leces Village, Leces District Probolinggo.

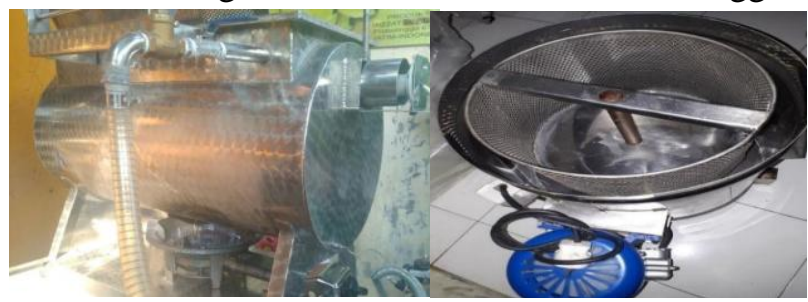

Figure 1. Vacuum Frying and Spinner machines at IKM Faizzat

\section{Testing of Vacuum Frying and Spinner Machines}

The Implementation Team conducts machine testing by operating vacuum frying and spinner machines in the production of sale and banana 
chips. IKM Owner. Faizzat has basic skills in machine science and electricity. These basic skills and the experience of partners in manual production are very helpful in testing machines to produce a variety of quality processed banana products. Production and testing activities are shown in Figure 2.

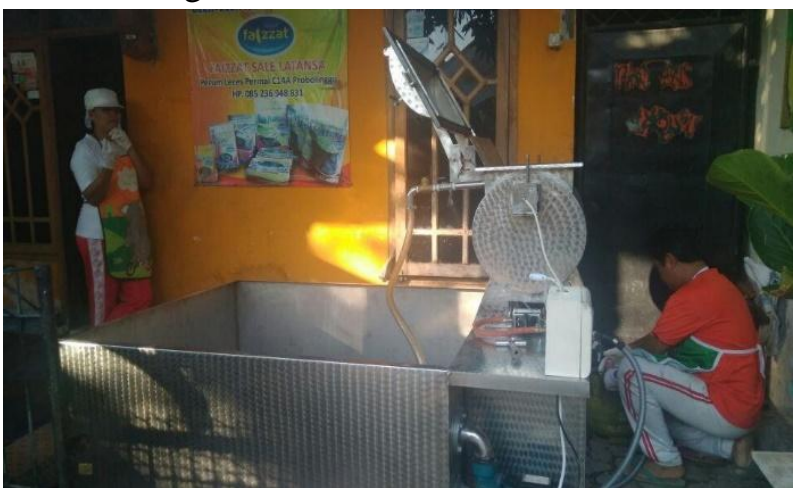

Figure 2. Adjusting the Components of a Vacuum Frying Machine

Standard Operating Procedure (SOP) process of frying raw bananas into various processed banana products (sale and banana chips) as follows:

\section{Preparation Phase for Banana Fruit Material}

Choose bananas with a certain level of maturity (not raw and not too ripe) and the fruit flesh is not too thick. Then peel the skin, drain and if necessary, do it broadcast.

\section{Banana Frying Frying Stage}

1. Fill the water bath up to $\pm 5 \mathrm{~cm}$ (750 liters) from the surface of the tub circulation.

2. Add the cooking oil to the tube until the bottom of the basket fruit.

3. Make sure the button controls the temperature in the off position when connecting the LPG regulator with tube.

4. Check the position of the needle setting temperature at $80^{\circ} \mathrm{C}-90^{\circ} \mathrm{C}$, connect the temperature control plug box with 220 Volt electricity and a minimum of 1300 Watt.

5. Press the temperature control button on position and turn on the stove gas.

6. After the set temperature is reached (marked by the stove light shrinking), add the maximum ingredients of $10 \mathrm{~kg}$ into the frying basket and Closed.

7. Attach the lid of the frying tube and tight lock, close the vacuum release faucet, turn on the pump by pressing the large button in position on the control box while opening the tap of water circulation above the jet tube, wait until the water comes out of the top hose condenser.

8. After the vacuum meter shows the number 700 $\mathrm{mmHg}$, lower the basket into the oil by rotating the stirrer lever half a rotation $\left(180^{\circ} \mathrm{C}\right)$. Shake the lever every 5 minutes for leveling heating.

9. When the material is put into oil, the temperature will drop, the vacuum meter needle moves to the right, the surveillance glass becomes dewy.

10.When ripe, the froth on the frying tube will disappear (seen from the reconnaissance glass by pressing the light switch to the on position), lift the material over the oil by rotating the $180^{\circ}$ stirrer lever and lock. Turn off the pump, stove, and water circulation tap, then open the vacuum release tap (above the lid), up to a vacuum meter pointing 0 .

11.Open the tube lid and frying basket, lift the chips banana.

\section{Drying Phase of Banana Chips}

1. Add the fried banana chips to a maximum of 5 $\mathrm{kg}$ into the basket or basketball.

2. Make sure the cable has been connected to 220 Volt electricity and at least 900 Watt because it only requires 700 Watt.

3. Press the on button so the basket or basket rotates to drain the remaining oil on the chips banana.

4. After drying, turn off the button, lift the banana chips ready packed.

\section{Training Activities}

The Implementation Team conducted training and mentoring various production of processed bananas in the form of sale and banana chips with vacuum frying and spinner machines. In this training IKM Faizzat owners and employees recruited from neighboring housing were invited to jointly produce banana chips based on SOP and clothing standards. The goal is that partner banana processed products have standard quality and meet food hygiene and health aspects. Production training activities are shown in Figure 3. 


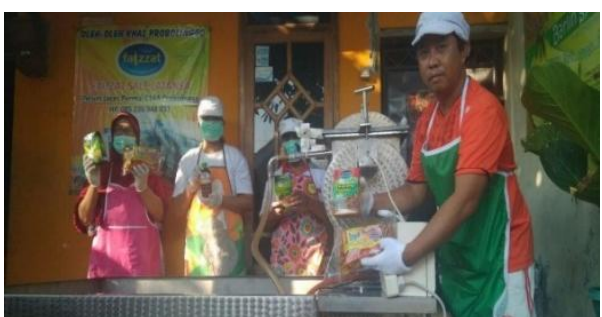

Figure 3. Training on Production of Sale and Banana Chips

\section{Socialization}

The Implementation Team disseminated information to partners and the community about the benefits of appropriate technology for vacuum frying and spinner to improve the quality of banana chips and sale products from partners, packaging design innovations and product labeling to increase consumer value and trust, and partner business development through diversified processed products banana. The design of various bananaprocessed product packaging is shown in Figure 4.

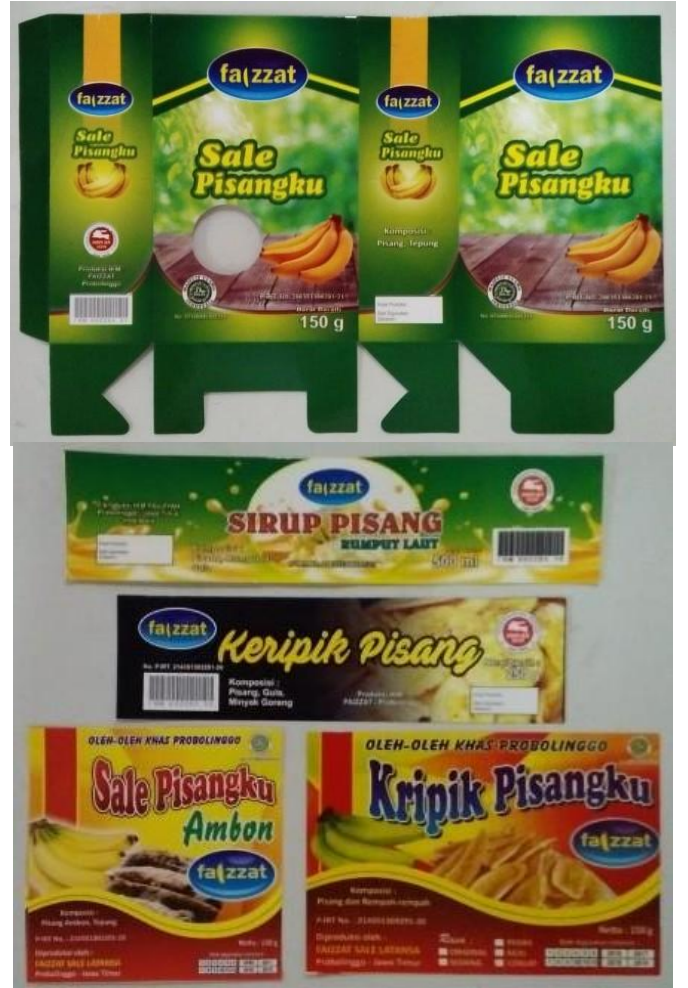

Figure 4. Sale of Banana Packaging Products in a Box

\section{Stage Activities that Have Been Done}

As a result of the following activities were training and assistance in the preparation of financial models, organoleptic testing and nutrition laboratories to improve the quality control of banana processed products, network expansion marketing of SME products at the local and national level, monitoring and evaluating the development and sustainability of businesses, the range of scientific publications and national newspapers are explained in Table 10.

Table 4. Stages of Service that have been carried out

\begin{tabular}{|c|c|c|}
\hline No. & Activities & Description \\
\hline 1. & $\begin{array}{l}\text { Training and } \\
\text { mentoring } \\
\text { preparation of } \\
\text { financial } \\
\text { models. }\end{array}$ & $\begin{array}{l}\text { Training and mentoring activities to } \\
\text { make administration and report } \\
\text { finance standard needs UKM and } \\
\text { SOUP Enumeration of purchases, } \\
\text { production, sales, payroll and reporting } \\
\text { transactions. }\end{array}$ \\
\hline 2. & $\begin{array}{l}\text { Organoleptic } \\
\text { testing and } \\
\text { laboratory } \\
\text { nutrition on the } \\
\text { final product }\end{array}$ & $\begin{array}{l}\text { Organoleptic testing activities include } \\
\text { texture, aroma and taste to ensure the } \\
\text { product is in accordance with quality } \\
\text { standards. Laboratory nutrition testing } \\
\text { activities to find out the womb } \\
\text { nutrition in every product presentation. } \\
\text { Nutritional information will be } \\
\text { delivered to customers in product } \\
\text { packaging. }\end{array}$ \\
\hline 3. & $\begin{array}{l}\text { Expansion of } \\
\text { SME product } \\
\text { marketing } \\
\text { networks at } \\
\text { local and } \\
\text { national levels }\end{array}$ & $\begin{array}{l}\text { Marketing activities focused on search } \\
\text { activities and the addition of marketing } \\
\text { agents, participation in SME product } \\
\text { exhibitions and trade missions that are } \\
\text { held well by } \\
\text { IKM associations and elements of } \\
\text { district, provincial and national } \\
\text { government. }\end{array}$ \\
\hline 4 & $\begin{array}{l}\text { Monitoring and } \\
\text { evaluating } \\
\text { business } \\
\text { development and } \\
\text { sustainability }\end{array}$ & $\begin{array}{l}\text { Activities for monitoring and } \\
\text { evaluating the development and } \\
\text { sustainability of business are carried out } \\
\text { on partners related to production and } \\
\text { marketing activities and financial } \\
\text { administration. The purpose of } \\
\text { monitoring and evaluation is to find out } \\
\text { the business development and } \\
\text { completion obstacles } \\
\text { or obstacles in running a business. }\end{array}$ \\
\hline 5 & Publication output & $\begin{array}{l}\text { Publications include national seminars } \\
\text { and or journals } \\
\text { ISSN community service, newspaper } \\
\text { articles and book publishing ISBN. }\end{array}$ \\
\hline
\end{tabular}

\section{Conclusions}

The conclusions of the Community Partnership Program (PKM) activities regarding the application of vacuum frying machines on Banana Processed IKM to increase the income of former PT Kertas Leces layoff employees in Probolinggo Regency, East Java include: (1) The Implementation Team has carried out the procurement and testing of vacuum frying machines and spinner according to the capacity of $10 \mathrm{~kg}$ according to the needs of partners. Testing the machine in production activities to ensure the machine can function properly and obtain a standard of treatment as outlined in the Standard Operating Procedure (SOP), (2) Training and 
mentoring activities in producing various banana preparations, especially sale and banana chips based on SOP to produce product quality standard,

(3) Dissemination activities are carried out to partners and the community to know the benefits of appropriate technology, packaging design and labeling innovations, and diversification of banana processed products. The aim is to provide confidence and optimism in entrepreneurship and can use technology in an effort to improve product quality and development business, (4) training activities in making financial statements that are more accountable, transparent and bankable (5) marketing network development activities to further develop the marketing area of the products produced, through pamera activities, both at local and national levels.

Suggestions for the next business development are always to carry out further experiments on the use of vacuum frying and spinner machines to produce better quality of various banana processed products by utilizing local raw materials, business development in the form of diversification of banana-based processed products such as banana syrup and other derivative products high selling value. In addition, organoleptic testing and nutritional oratory labs are needed to maintain quality standards and nutritional adequacy written on packaging, packaging design innovations and labeling various banana-processed products as well as the additional permits needed to compete with similar products.

\section{References}

Agricultural Research Agency, 2013. Banana Hump Crackers: From Nutrients Rich in Nutrition to Our Dining Tables. Agroinovasi, April 24-30 2013 Edition No. 3504.

Ministry of Agriculture, 2014. Outlook for Banana Commodities. Journal of Agricultural Information Systems and Data Center Secretariat General Ministry of Agriculture, ISSN 1907-1507

Pary et al., 2016. Analysis of Nutritional Content of Kepok Banana Skin Waste (Musa Paradisiaca Formatypica) as Crackers Raw Material. Journal of Biology Science \& Education, Vol 5 No.
1 Edition January-June 2016 ISSN 2252$858 \mathrm{x}$

Setyadjit, 2010. Processing Technology

Diffusion (7 Processed Products) To

Farmers / Gapoktan Groups With Target of 2 Production Units and Can Increase Product Value Added 50\%, Center for Agricultural Postharvest Research and

Development, Ministry Agriculture

http://www.lppm.unmuhjember.ac.id (Accessed

June 3, 2017

http://www.wartabromo.com (Accessed June 1, 2017)

http://www.beritamoneter.com (Accessed June 1, 2017)

http://bpbd.probolinggokab.go.id (Accessed June $1,2017)$ 